J. Perinat. Med. 3 (1975) 172

\section{Heart rate in fetuses and neonates in normal conditions and with mild depression}

\author{
R. Bustos, R. Béjar, H. Arroyave, A. J. D. Jacomo, M. Burghi, F. Ramí- \\ rez, Ma. C. Cordano, V. Curbelo, O. Guayasamin, Ma. R. Minetti, \\ L. Guemberena, R. Caldeyro-Barcia
}
Latin American Center of Perinatology and Human Development Montevideo, Uruguay

Received October 25, 1974. Accepted November 10, 1974.
The continuous recording of fetal and neonatal heart rate gives reliable information on the condition of the fetus and neonate $[7,8,21,22$, 23]. During delivery, in response to the different acting stimuli, marked fetal bradycardias are usually produced.

Immediately after birth, and if pulmonary ventilation starts normally, neonatal heart rate rises significantly during the first minutes of life, and then falls gradually until it becomes stabilized at values similar to those of fetal heart rate $[4,5,6$, $11,15]$.

In the present study the results obtained in vigorous and mildly depressed newborns $[1,2$, 3,13 ] by the continuous recording of fetal heart rate during labor and of neonatal heart rate during 90 minutes after birth, are presented.

\section{Material and methods}

Twenty three pregnant women were studied during labor, as well as their newborns. They fulfilled the following conditions:

- Mothers without known complications and good prenatal care.

- Term pregnancies with single fetuses in vertex presentation with birthweight normal for age [17].

- All labors started, progressed and delivered spontaneously without signs of fetal distress.

- No drugs were given to the mother during labor, or to the neonate $[12,16,18,20]$.

\section{Curriculum vitae}

José Raúl Bustos, $M . D$., born in Montevideo, Uruguay in 1944. Graduated as Doctor in Medicine at the School of Medicine, University of Uruguay', Montevideo in 1969. In 1971 be started postgraduate studies in Pediatrics at the School of Medicine of Montevideo, and was awarded the degree of Pediatrician in 1974. In 1965 be started working in research at the Service of Obstetrical Physiology under the direction of Professor Roberto Caldeyro-Barcia, becoming Research Assistant in 1967. At present, he bas become Cbief of the Section of Obstetrical Pbysiology of the School of Medicine, University of Uruguay.

Since 1970 be is working as Perinatologist at the Latin American Center of Perinatology and Human Development (CLAP) fulfilling bis main duties in the Neonatology Service, University Hospital, Montevideo.

He bas been short-term consultant in Perinatology of the Pan American Health Organization/World Health Organization on several occasions Brazil.

The umbilical cord was clamped immediately after birth.

Seventeen neonates were vigorous at 1 and 5 minutes (APGAR score 7 or higher). Six neonates were slightly depressed at the first minute but all of them recovered at 5 minutes. Both groups are studied separately.

Fetal heart rate (FHR) was continuously recorded for at least 90 minutes before delivery 
with a cardiotachometer. Uterine contractions were recorded simultaneously on the same paper, by a transcervical catheter. The record of neonatal heart rate (NHR) was started as soon as possible after delivery, and lasted for at least 90 minutes. The cardiotachometer was triggered by the ECG [19] obtained with two HoN electrodes (one under the scalp and the other in the umbilical cord). Punctures of the heel (after warming) were made to obtain neonatal blood samples at $15,30,60$ and 90 minutes of life. The infants were kept naked in an adequate room, warmed with infrared rays. Skin temperature which was controlled every 15 minutes, remained between 36 and $37^{\circ} \mathrm{C}$.

The records of FHR were analyzed as follows. Baseline Fetal Heart Rate (BFHR) was measured every 2 minutes according to the method of Caldeyro-Barcia et al. [7]. Neonatal heart rate was measured every 30 seconds, and the average for every 4 consecutive values was calculated. For the statistical analysis of heart rate, the averages corresponding to minutes 60,30 and 8 before delivery, and minutes 10,50 and 80 after birth were chosen. The " $t$ " test for dependent samples and the linear correlation test were used.

\section{Results}

Figure 1 shows the average values of BFHR and NHR corresponding to 17 vigorous newborns (APGAR scores 7-10 at the first and fifth minutes of life).

No major variations were found in the average values of BFHR in the time period studied. No statistically significant differences were found in the BFHR of the same fetus at 60,30 and 8 minutes before delivery (Fig. 2).

This result indicates that the BFHR of each fetus remains within a given range during the last 60 minutes preceding delivery. A nonsignificant decrease in BFHR occurred during the 6 minutes preceding birth (Fig. 1).

After birth the average values of NHR were higher than the fetal ones (Fig. 1). This postnatal increase in heart rate ( 32 beats $/ \mathrm{min}$ ) is statistically significant when BFHR values 30 minutes before delivery are compared with NHR values recorded 10 minutes after birth (Fig. 3). No correlation was found between the pair of values corresponding to each infant. A significant negative linear correlation (Fig. 4) was found between values of BFHR 30 minutes before delivery and the amplitude of the

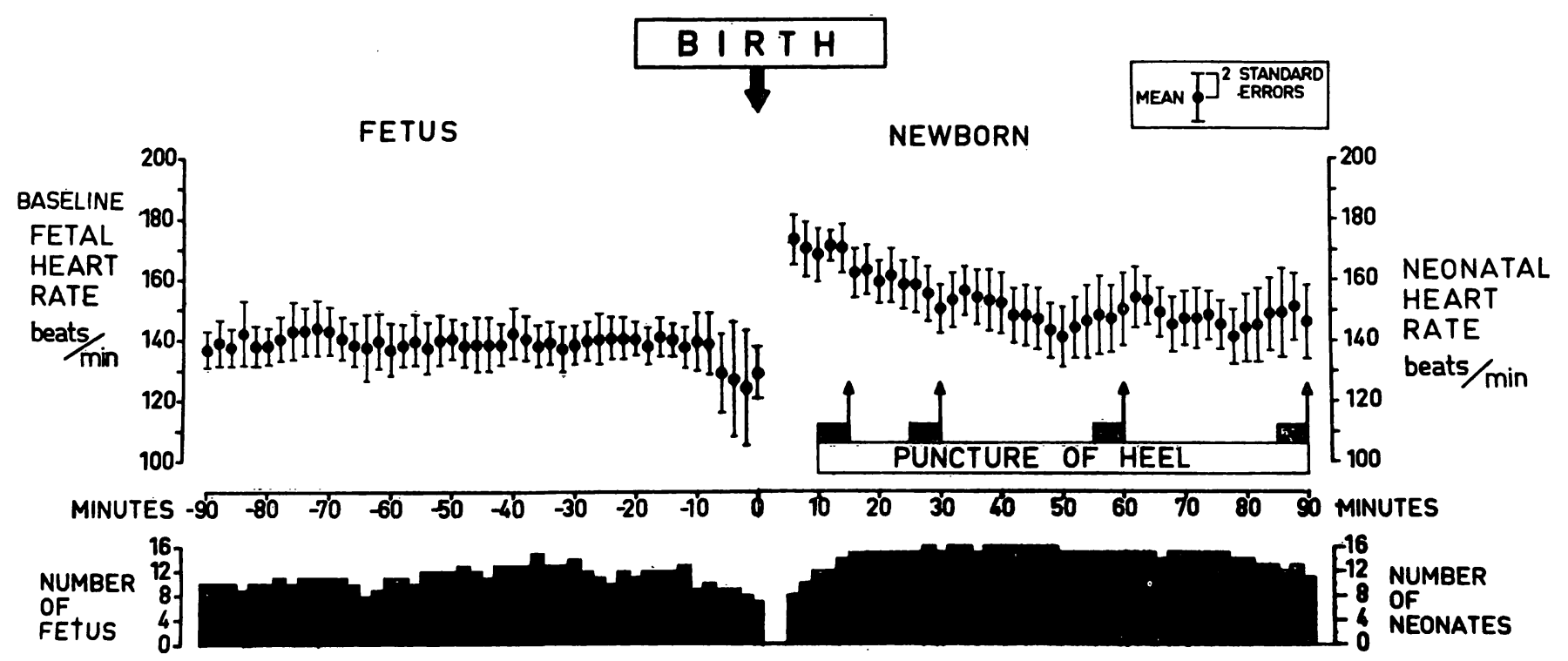

Fig. 1. Average values of 17 normal labors and corresponding neonates. Fetal heart rate is stable during the 90 minutes preceding delivery. After birth there is a sudden and marked rise in neonatal heart rate followed by a gradual fall lasting 50 minutes. Neonatal heart rate then became stable at a level similar to that of Baseline Fetal Heart Rate (BFHR). Puncture of the heel caused a transient rise in heart rate. 


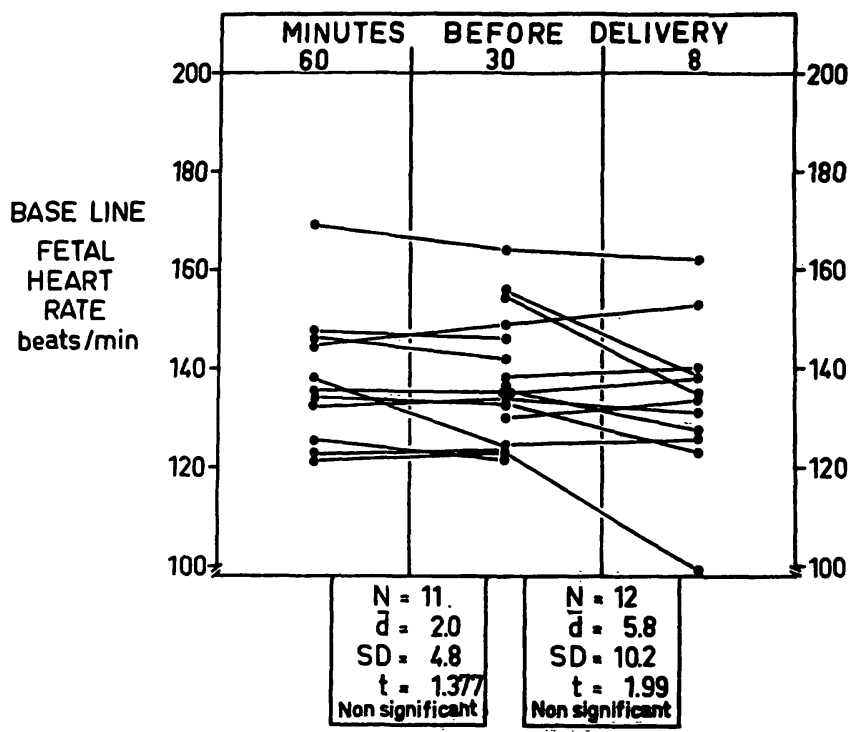

Fig. 2. No significant differences are found in FHR at 60,30 and 8 minutes before delivery. The BFHR of each fetus remains within a given range.

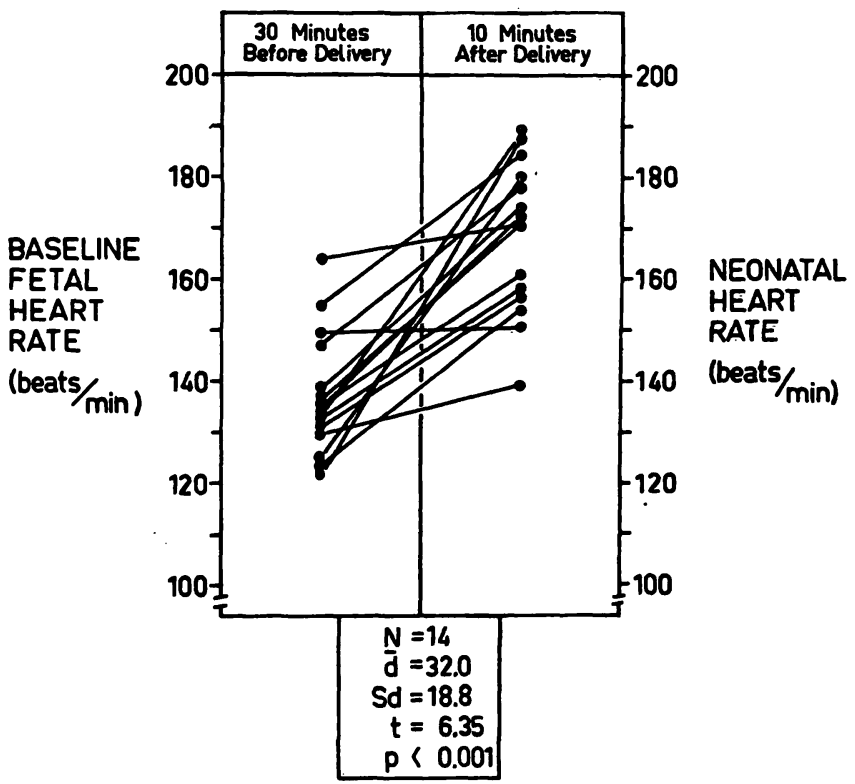

Fig. 3. Neonatal heart rate (NHR) 10 minutes after birth is significantly higher than BFHR 60 minutes before delivery.

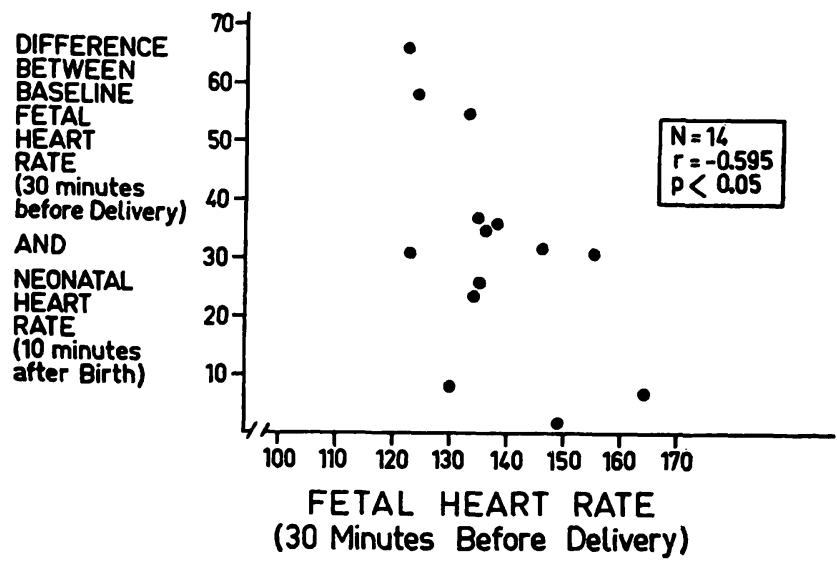

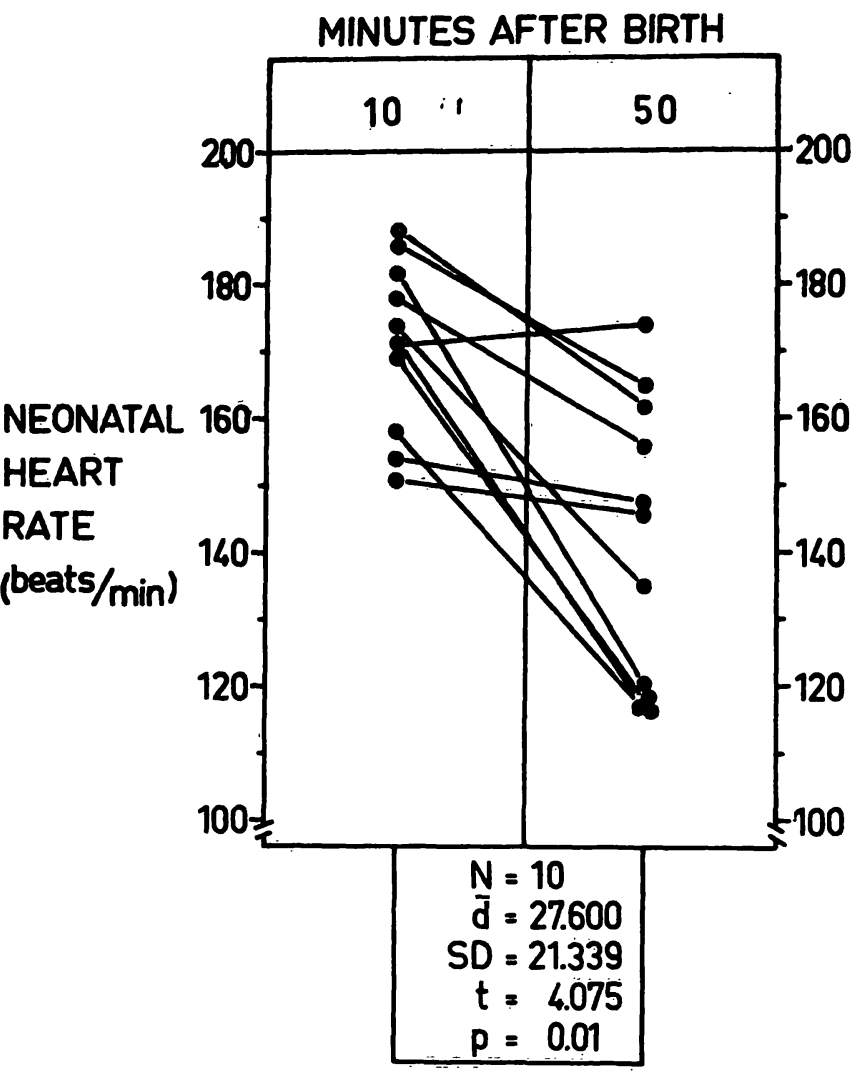

Fig. 5. Fifty minutes after birth, NHR is significantly lower than 10 minutes after birth.

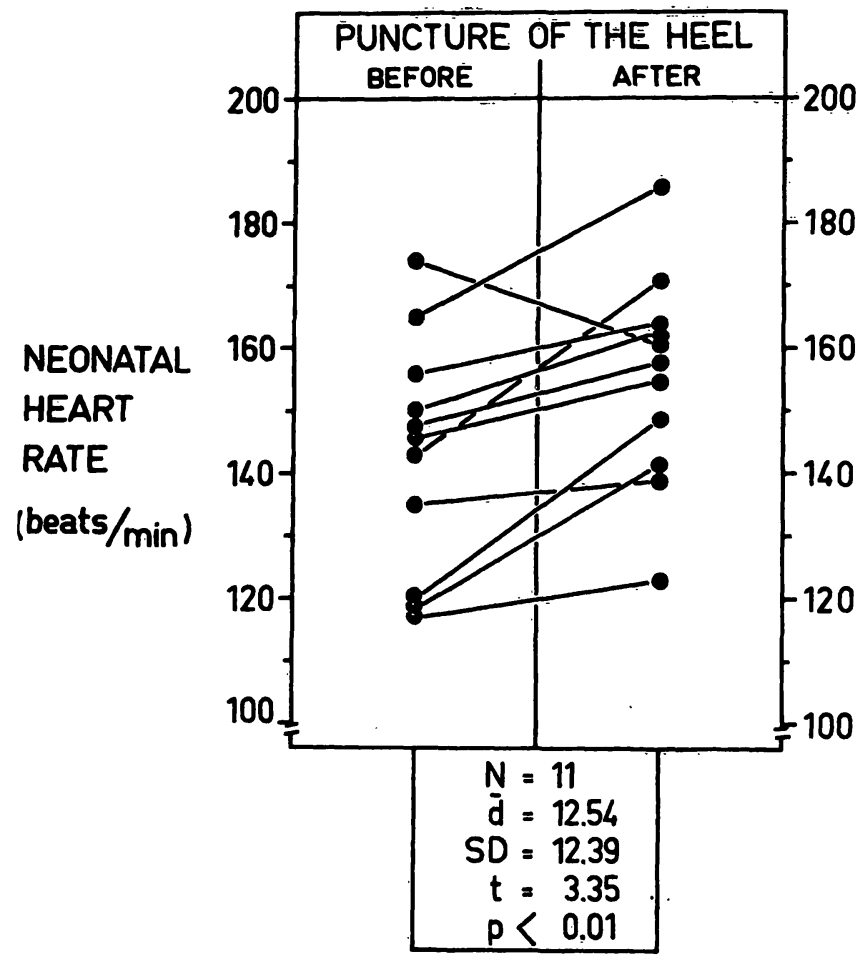

Fig. 6. Puncture of the heel causes a significant tise in NHR.

Fig. 4. The higher the BFHR, the lower the increment in NHR occurring after birth. 
Tab. I. Blood from umbilical artery at birth.

\begin{tabular}{ccccc}
\hline & $\mathrm{pH}$ & $\mathrm{PCO}_{2}$ & Base Excess & $\mathrm{PO}_{2}$ \\
\hline Vigorous & 17 & & & \\
$\mathrm{~N}$ & 7.28 & 13 & 13 & 14 \\
$\mathrm{X}$ & 0.10 & 46.8 & -4.0 & 24.6 \\
$\mathrm{SD}$ & 0.22 & 12.8 & 3.4 & 8.9 \\
$\mathrm{SE}$ & 3.5 & 0.9 & 2.4 \\
Slightly depressed & 4 & & & \\
$\mathrm{~N}$ & 7.27 & 56.5 & -4.5 & 4 \\
$\widetilde{X}$ & 0.14 & 27.6 & 1.7 & 6.4 \\
$\mathrm{SD}$ & 0.07 & 13.8 & 0.9 & 3.2 \\
$\mathrm{SE}$ & $\mathrm{t}=0.130$ & $\mathrm{t}=1.00$ & $\mathrm{t}=0.262$ & $\mathrm{t}=0.394$ \\
& & &
\end{tabular}

Not significant

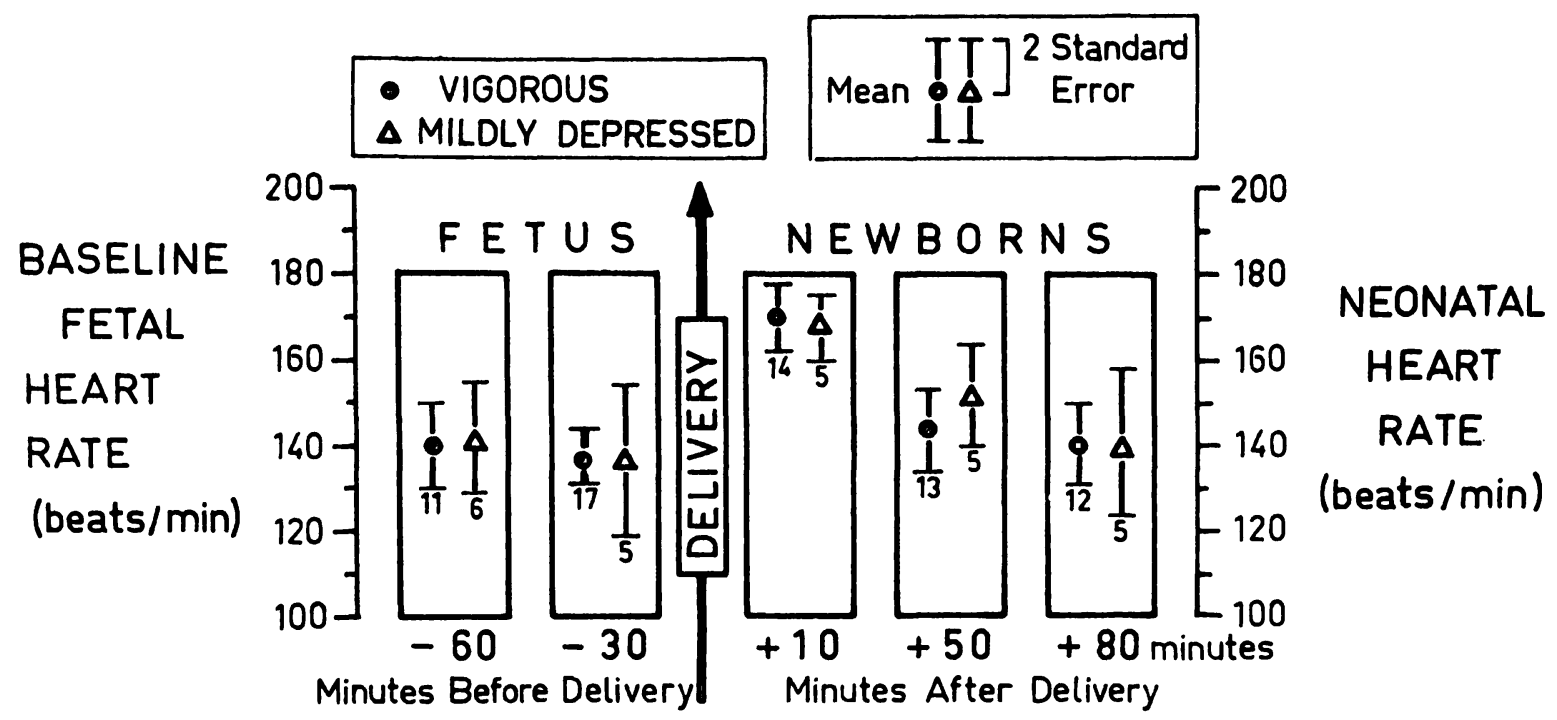

Fig. 7. There is no significant difference in heart rate (fetal or neonatal) between infants which were vigorous or slightly depressed at the first minute after birth.

increase occurring after birth as measured in Fig. 3. After this initial increase, NHR starts a gradual fall, lasting about 50 minutes and then becomes stable at a level similar to that of fetal heart rate (Fig. 1). The average BFHR at 30 minutes before delivery was not significantly different from NHR at 50 minutes after birth.

NHR average values at 10 and 50 minutes after birth were compared: the difference was significant $(p<0.01)$ (Fig. 5). No difference was found between NHR values at 50 and 80 minutes after birth.

Figure 1 shows that puncture of the heel causes an increase in NHR. The difference between NHR before and after the punctures is significant (Fig. 6). The heart rate of 6 infants which were slightly depressed at the first minute of life (APGAR score 4-6) but vigorous at the fifth minute, was analyzed with the same methods described. The corresponding values of BFHR and NHR are not significantly different from those of the group of 17 neonates vigorous from the first minute (Fig. 7). In addition, no significant differences were found between both groups in the $\mathrm{P}_{\mathrm{O}_{2}}, \mathrm{P}_{\mathrm{CO}_{2}}, \mathrm{pH}$ and Base Excess of blood of umbilical artery clamped immediately after birth (Tab. I).

\section{Discussion}

The cases chosen for this study have been carefully selected with the aim of establishing the "normal" pattern of fetal and neonatal heart 
rate. Therefore, all newborns were vigorous at the fifth minute, spontaneously born, term infants whose mothers had no known pathologies and had not received any medication during labor.

Our results suggest that BFHR follows a stable pattern during the 90 minutes preceding delivery, at values which agree with those already described (Figs. 1 and 2) [11].

The individual study of these cases shows a certain dependence between values of BFHR at the end of labor, and the preceding ones (Fig. 2).

The transient rise in NHR during the first minutes of life is most probably due to the stress of the last stages of labor $[5,6,15]$.

The lack of correlation between values of fetal and neonatal heart rates suggests that an independent pattern is established after birth. From the data obtained we may state that 50 minutes after birth there is a relative stabilization of NHR.

The average values of NHR reported by Bustos and GRISARD $[5,6]$ were lower than those presented in this paper. Also, stabilization was reached earlier (at 30 minutes) $[5,6]$. It should be pointed out that in that study $[5,6]$ the mothers received analgesic drugs, and no punctures of the heel of the newborn were made. This last maneuver has been shown to cause an increase in heart rate (Fig. 6).

\section{Summary}

The continuous recording of fetal and neonatal heart rate gives reliable information on the condition of the fetus and neonate.

In the present study the results obtained in vigorous and mildly depressed newborns, by the continuous recording of fetal heart rate during labor and of neonatal heart rate during 90 minutes after birth, are presented.

Twenty three pregnant women were studied during labor, as well as their newborns. They fulfilled the following conditions:

- Mothers without known complications and good prenatal care.

- Term pregnancies with single fetuses in vertex presentation with birthweight normal for age.

- All labors started, progressed and delivered spontanously without signs of fetal distress.

No drugs were given to the mother during labor or to the neonate. The umbilical cord was clamped immediately
In the present paper no difference in NHR was found between vigorous and slightly depressed newborns which had all recovered at the fifth minute. In a group of severely depressed neonates (APGAR score 6 or less at the first and fifth minutes of life), Bustos and GRISARD $[5,6]$ reported that NHR was significantly higher than in a control group of vigorous neonates. This difference lasted for at least 30 minutes. The higher NHR of the neonates which had undergone perinatal asphyxia may be interpreted as a rebound tachycardia occurring in the recovery period $[5,6,9,10,14,15]$.

\section{Conclusions}

1. In normal term labors BFHR remains stable from 90 until 10 minutes before délivery.

2. There is a tendency for BFHR to fall during the last 6 minutes preceding birth.

3. The average values of neonatal heart rate (NHR) at 10 minutes of life, are significantly higher than those of BFHR.

4. NHR is stabilized 50 minutes after delivery, at similar levels to those of BFHR.

5. In the group of slightly depressed newborns at the first minute of life, fetal and neonatal heart rates were not very different from values corresponding to vigorous newborns.

after birth. Seventeen neonates were vigorous at 1 and 5 minutes (APGAR score 7 or higher). Six neonates were slightly depressed at the first minute but all of them recovered at 5 minutes. Both groups are studied separately.

Figure 1 shows the average values of BFHR and NHR corresponding to 17 vigorous newborns (APGAR scores $7-10$ at the first and fifth minutes of life).

No major variations were found in the average values of BFHR in the time period studied. No statistically significant differences were found in the BFHR of the same fetus at 60,30 and 8 minutes before delivery (Fig. 2). A decrease in BFHR occurred during the 6 minutes preceding birth (Fig. 1).

After birth the average values of NHR were higher than the fetal ones (Fig. 1). This post-natal increase in heart rate ( 32 beats/min) is statistically significant when BFHR values 30 minutes before delivery are compared with NHR values recorded 10 minutes after birth (Fig. 3). After this initial increase, NHR starts a gradual fall, lasting about 
50 minutes and then becomes stable at a level similar to that of fetal heart rate (Fig. 1).

Figure 1 shows that puncture of the heel causes an increase in NHR. The difference between NHR before and after the puncture is significant (Fig. 6). The heart rate of 6 newborns which were slightly depressed at the first minute of life (APGAR score 4-6) but vigorous at the fifth minute, are not significantly different from those of the vigorous group of 17 neonates (Fig. 7).
The cases chosen for this study have been carefully selected with the aim of establishing the "normal" pattern of fetal and neonatal heart rate.

We concluded that in normal term labors BFHR remains stable from 90 until 10 minutes before delivery; there is a tendency to fall during the last 6 minutes preceding birth.

Immediately after birth, neonatal heart rate rises significantly, then falls gradually and becomes stabilized 50 minutes after delivery, at levels similar to those of BFHR.

Keywords: Baseline, fetal heart rate, medicaments (during labor), neonatal heart rate, normal deliveries, normal pregnancies vigorous newborns.

\section{Zusammenfassung}

Herzfrequenz des Feten und Neugeborenen bei normalen Bedingungen und bei leichter Beeinträchtigung

Die kontinuierliche Registrierung der Herzfrequenz des Feten und des Neugeborenen gibt verläßliche Informationen über deren Befinden. In der vorliegenden Arbeit werden die Ergebnisse der kontinuierlichen Herzfrequenzregistrierung während der Fetalzeit, während der Geburt und während der Neugeborenenperiode bis 90 Minuten nach der Geburt vorgestellt, die man bei lebensfrischen und leicht deprimierten Neugeborenen erhielt.

23 Kreißende und ihre Kinder wurden untersucht. Die Bedingungen waren folgende:

- Mütter ohne bekannte Komplikationen und mit guter Schwangerenfürsorge.

- Termingerechte Schwangerschaften ausschließlich mit Schädellage und mit einem der Norm entsprechenden Geburtsgewicht.

- Alle Geburten waren spontan, ohne Zeichen einer Beeinträchtigung des Feten.

Den Müttern und Neugeborenen wurden während der Geburt keinerlei Medikamente verabreicht. Die Nabelschnur wurde unmittelbar nach der Geburt abgeklemmt. 17 Neugeborene waren lebensfrisch nach 1 und 5 Minuten (APGAR-Score 7 oder höher). 6 Neugeborene waren leicht deprimiert nach 1 Minute, doch alle erholten sich nach 5 Minuten. Beide Gruppen wurden getrennt untersucht.

Fig. 1 zeigt die Durchschnittswerte der basalen fetalen Herzfrequenz (BFHR) und des neonatalen Herzfrequenz(NHR), die sich auf die 17 lebenskräftigen Neugeborenen (Apgar-Scores 7-10 in der 1. und 5. Minute) beziehen. Keine stärkeren Schwankungen wurden in den Durchschnittswerten der BFHR während der Untersuchungszeit gefunden. Keine statistisch signifikanten Unterschiede der BFHR wurden beim gleichen Feten 60, 30 und 8 Minuten vor der Geburt gefunden (Fig. 2). Eine Verminderung der BFHR ergab sich während der 6 der Geburt vorangehenden Minuten (Fig. 1).

Die Durchschnittswerte der NHR waren nach der Geburt höher als die in der fetalen Zeit (Fig. 1). Diese postnatale Zunahme der Herzfrequenz (32 Schläge/min.) ist statistisch signifikant, wenn man die 30 Minuten vor der Entbindung erhaltenen BFHR Werte mit den 10 Minuten nach der Geburt registrierten NHR Werten vergleicht (Fig.3). Nach anfänglicher Zunahme fällt die NHR graduell während 50 Minuten und stabilisiert sich dann in etwa einer Höhe der fetalen Herzfrequenz (Fig. 1).

Fig. 1 zeigt, daß die Punktion der Ferse ein Ansteigen des NHR verursacht. Der Unterschied der NHR vor und nach der Punktion ist signifikant (Fig. 6). Die Herzfrequenz von 6 Neugeborenen, die in der ersten Minute leicht deprimiert (Apgar-Score 4-6) jedoch in der 5. Minute lebensfrisch waren, unterscheidet sich nicht signifikant von denen der Gruppe von 17 lebensfrischen Neugeborenen (Fig. 7).

Der Zweck der Untersuchung dieser Fälle bestand darin, Normwerte für die Herzfrequenz im Fetal- und Neugeborenenalter zu gewinnen.

Wir folgerten, daß bei termingerechten Geburten die BFHR von der 90. bis 10. Minute vor der Geburt konstant bleibt. In den 6 Minuten vor der Geburt besteht eine abfallende Tendenz.

Unmittelbar nach der Geburt steigt die Herzfrequenz des Neugeborenen signifikant an, fällt dann graduell und stabilisiert sich 50 Minuten nach der Geburt in einer der BFHR entsprechenden Höhe.

Schlüsselwörter: Basalfrequenz, Geburt (normale), Herzfrequenz (Fet), Herzfrequenz (Neugeborenes), Medikamente (sub partu), Neugeborenes (lebensfrisch), Schwangerschaft (normale).

\section{Résumé}

Fréquence cardiaque chez le foetus et le nouveau-né dans des conditions normales et en présence d'une légère dépression

L'enregistrement continuel de la fréquence cardiaque foetale et néonatale donne une information précise sur la condition du foetus et du nouveau né.
Dans cette étude on présente les résultats obtenus chez des nouveaux nés vigoureux et légèrement déprimés, par l'enregistrement continuel de la fréquence cardiaque foetale pendant l'accouchement et de la fréquence cardiaque néonatale au cours des premières 90 minutes après la naissance. 
On a enregistré vingt-trois femmes enceintes pendant l'accouchement, aussi bien que ses nouveaux nés. Ils remplissaient les conditions suivantes:

- Mères sans aucune complication connue et avec une attention prénatale soignée.

- Grossesses à terme avec des foetus uniques en présentation de vertex, et d'un poids à la naissance normal pour l'âge.

- Le commencement, la progression et la terminaison de tous les accouchements furent spontanés, sans aucun signal de détresse foetale.

Aucune médication fut administrée aux mères pendant l'accouchement, et non plus aux nouveaux nés. Le cordon ombilical fut lié immédiatement après la naissance. Dixsept nouveaux nés étaient vigoureux à la lère. et à la 5ème minute (APGAR 7 ou supérieur). Les autres six étaient légèrement déprimés à la première minute mais tous se sont récupérés à la 5ème. Les deux groupes furent étudiés séparément.

La Fig. 1 montre les moyennes de la fréquence cardiaque foetale de base (FCFB) et de la néonatal (FCN) des 17 nouveaux nés vigoureux (APGAR 7-10 à la lère. et à la 5ème. minute).

Au cours du temps étudié, on n'a pas trouvé des variations importantes de la fréquence cardiaque foetale de base (FCFB). Il n'y a pas des différences statistiquement significatives chez un même foetus aux 60,30 et 8 minutes avant l'accouchement (Fig. 2). Il y a eu une diminution de la FCFB dans les 6 dernières minutes avant la naissance (Fig. 1). Après la naissance, les moyennes de la FCN furentiplus élevées que celles du foetus (Fig. 1). Cet accroissement post-natal de la fréquence cardiaque ( 32 battements/minute) est statistiquement significatif quand on fait la comparaison des chiffres de la FCFB 30 minutes avant la naissance, avec les moyennes de la FCN 10 minutes après celle-ci (Fig. 3). Ensuite, la FCN commence à diminuer graduellement, et depuis $\mathbf{5 0}$ minutes elle reste fixée à un niveau semblable à celui de la FCF (Fig. 1).

La Fig. 1 montre que la ponction du talon cause un incrément de la FCN. La différence entre la FCN avant et après la ponction est significative (Fig. 6). La fréquence cardiaque des 6 enfants qui étaient légèrement déprimés à la première minute (APGAR 4-6) mais récupérés à la 5ème, n'est pas significativemente différente de celle du groupe vigoureux (17 nouveaux nés) (Fig. 7).

Les cas choisis pour cette étude ont été soigneusement sélectionnés pour établir un patron "normal" de la FCF et de la FCN.

Nous sommes arrivés à la conclusion que la FCFB demeure la même dès 90 jusqu'aux 10 minutes avant la naissance. Elle montre une tendance à tomber pendant les 6 minutes qui précèdent celle-ci.

Immédiatement après la naissance, la FCN augmente significativement, pour retomber graduellement et devenir stable depuis 50 minutes à des niveaux similaires à ceux de la FCFB.

Mots-clés: fréquence basale, fréquence cardiaque (nouveau-né), fréquence cardiaque (foetus), grossesse (normale), médicaments (sub partu), naissance (normale), nouveau-né (sain).

\section{Bibliography}

[1] APGAR, V.: A proposal for a new method of evaluation of the newborn infant. Curr. Res. in Anesth. Analgesia (1953) 260

[2] Apgar, V., D. A. Holaday, L. S. James, I. M. Weisbrot, A. B. Cornelia Berrier: Evaluation of the newborn infant. Second Report. J. A. M. A. 168 (1958) 1985

[3] Apgar, V., L. S. James: Los primeros sesenta segundos de vida. In: Abramson, H.: Reanimación del Recién Nacido. Salvat, Barcelona 1969

[4] Brady, J. P., L. S. James, M. A. Baker: Heart rate changes in the fetus and newborn infant during labor, delivery and the immediate neonatal period. Amer. J. Obstet. Gynec. 84 (1962) 1

[5] Bustos, R., N. Grisard, D. Fonseca: Influencia del sufrimiento fetal agudo intraparto sobre la evolución de la frecuencia cardíaca neonatal. In: R. RugGIA, ed., Primer Congreso Latinoamericano de Neuropediatría, Delta Editorial, Montevideo, Uruguay 1971

[6] Bustos, R., N. Grisard, D. Fonseca: Diferencia en la frecuencia cardíaca entre neonatos vigorosos $y$ deprimidos y con sindrome de dificultad respiratoria. In: Lisboa, A. M. J., L. Torres Barboza: Temas de Perinatología, CEPPLANC Brasilia 1970
[7] Caldeyro-Barcia, R., C. Ménddez-Baúer, J. J. Poseiro, L. Escarcena, S. V. Pose, J. Bieniarz, I. C. Arnt, L. A. Gulin, O. Althare: Control of human fetal heart rate during labor. In: Cassels, E. D.: The Heart and Circulation in the Newborn and Infant. Grune \& Stratton Inc., New York 1966

[8] Caldeyro-Barcia, R., J. J. Poseiro, C. MéndezBauer, L. A. Gulin: Effects of abnormal uterine contractions on fetal heart rate during labor. In: COPE, I.: Fifth World Congress of Obstetrics and Gynecology, Supplementary Main Papers. Butterworth, Sydney 1967

[9] Caldeyro-Barcia, R., L. A. Gulin, J. J. Poseiro, C. Méndez-Bauer, D. Fonseca, R. Ruggia, L. Escarcena, C. Casacuberta, R. Bustos, G. Giussi: Intrapartum disturbances in fetalhomeostasis and their correlation with respiratory distress syndrome and abnormal EEG in the child. In: DorfmaN, A.: Child Care in Health and Disease. Year Book Medical Publishers, Chicago 1968

[10] Caldeyro-Barcia, R.: Sufrimiento fetal intraparto. Fisiopatología. In: S. V. Pose, V Congresso Uruguayo de Ginecotocología, Imprenta Rosgal S. A., Montevideo 1969 
[11] Cordero, L. JR.: Heart Rate changes during the first hour of life. Biol. Neonate 20 (1972) 270

[12] Cosmr, E.: Efectos de la administración de orciprenalina al recién nacido. Presented at the Symposium on "Utero-Inhibitory drugs and their effects on mother, fetus and newborn". Punta del Este, Uruguay, 1970. Personal communication.

[13] Drage, J. S., H. Berendes: Apgar Scores and outcome of the newborn. Pediatric Clinics of North America 13 (1966) 635

[14] Flowers, C. E. JR.: The importance of the infant heart rate in resuscitation of the newborn. The Bull. Mat. Welfare 3 (1956) 10

[15] Fonseca, D., C. MÉndez-Bauer: La frecuencia cardíaca del recién nacido en el período postnatal immediato. In: S. V. PosE, IV Congreso Uruguayo de Ginecotocología, Tomo II, Imprenta Rosgal S. A. Montevideo 1964

[16] Fonseca, D., R. Bustos, N. Grisard, I. Delfino, J. L. Díaz Rossello, R. Bernardi, R. Ruggia: Efectos sobre el recién nacido, de la administración de orciprenalina a la madre durante el parto. Presented at the Symposium on "Utero-inhibitory drugs and their effects on mother, fetus and newborn". Punta del Este, Uruguay, 1970. Personal communication

[17] Lubchenco, L. O., C. Hansman, B. Boyd: Intrauterine growth as estimated from live-born birth weight data at 24 to 42 weeks of gestation. Pediatrics 32 (1963) 793
[18] Méndez-Bauer, C., G. Arellano-Hérnández, M. A. Zambrana, R. Caldeyro-Barcia, D. Fonseca, J. J. Poseiro: Acción de la atropina sobre la frecuencia cardíaca del recién nacido. In: S. V. Pose, IV Congreso, Uruguayo de Ginecotocologia, Tomo II, Imprenta Rosgal S. A. Montevideo 1964

[19] Pantie, J., C. Gómez Rogers, J. J. Poseiro: Electrocardiograma fetal. Técnicas. In: III Congr. Uruguayo Ginecotoc., Tomo III. Montevideo 1960

[20] Schifferli, P. Y.: La frecuencia cardíaca fetal a lo largo del embarazo. Estudio de la influencia del sistema nervioso autónomo sobre el cronotropismo cardiaco fetal. Arch. Ginec. Obstet. del Uruguay 23 (1968) 87

[21] Smrth, C. A.: The dynamics of circulation. In: C. A. SMrrh, Physiology of the newborn infant. Thomas, Illinois 1959

[22] Urbach, J. R., B. Phuvichit, H. Zweizig, E. Milligan, E. Carrington, M. Loveland, J. Williams, R. Lambert, A. Duncan, S. Farrel, P. Simons, I. Spurgeon: Instantaneous heart rate patterns in newborn infants. Amer. J. Obstet. Gynec. 93 (1965) 965

[23] Vallbona, C., M. M. Desmond, A. J. Rudolph, L. F. PAP, M. H. RebA, R. R. FrankLIN, J. B. Rush: Cardiodynamic studies in the newborn. II. Regulation of the heart rate. Biol. Neonat. 5 (1963) 159

Dr. Raúl Bustos

Centro Latinoamericano de Perinatologia y

Desarrollo Humano

Casilla de correo 627

Montevideo, Uruguay 